\title{
Popüler Kültür, Oyunlar ve Propaganda: Terörizmin Antropolojik Kodları
}

Teslim: 05 Șubat 2018

Onay: 29 Ağustos 2018

\section{Sefer DARICI* \\ Ebru KARADOĞAN ISMAYIL**}

\section{Öz}

Küreselleşme olgusu ve teknolojinin gelişmesine paralel olarak artan iletişim araçları, terör örgütlerinin de propaganda stratejilerinde değişiklikler yaratmıştır. DAEŞ terörörgütü de finans, örgüte katılım, faaliyetlerini duyurma vb. nedenlerle profesyonel propaganda videoları hazırlamakta ve tüm dünyaya değişik iletişim araçları ile yaymaktadır. Hedef kitle olarak tüm dünyayı seçen DAEŞ, videolarında ikna amacıyla popüler kültürün unsurlarını da kullanmaktadır. Nitel araştırma deseninde bir durum çalışması olarak yürütülen bu çalışmada DAEŞ'in propaganda videolarından 6'sı amaçlı örneklem yöntemlerinden ölçüt örnekleme ile seçilmiş ve içerik analizi yapılmıştır. Daha sonra bu veriler popüler TV dizileri (Person of Interest), filmler (American Sniper, Unthinkable), dijital oyunlar (Call of Duty, Grand Theft Auto, Medal of Honor, Sniper Ghost Warrior), film afişleri (The Expendables 2) ile karşılaştırılarak analiz edilmiştir. Sonuçlar DAEŞ'in antropolojik verileri, popüler kültürü ve Hollywood etkisini propaganda videolarında kullandığını göstermektedir. Bulgular sosyal antropoloji bağlamında tartışılarak yeni bir bakış açısı oluşturulmaya çalışılmıştır.

Anahtar Kelimeler: Antropoloji, Oyun, Terör, DAEŞ, Propaganda

* Sivas Cumhuriyet Üniversitesi

** Üsküdar Üniversitesi 


\title{
Populer Culture, Games and Propaganda: Anthropological Codes of Terrorism
}

\author{
Sefer DARICI* \\ Ebru KARADOĞAN ISMAYIL**
}

\begin{abstract}
The communication tools that have increased in parallel with the development of globalization and technology have also created changes in the propaganda strategies of terrorist organizations. The DAEŞ terror organization is also involved in financing, organized participation, it is preparing professional propaganda videos for reasons and spreading to the whole world with various tools of communication. Having chosen the whole world as its target audience, DAEŞ also uses popular cultural elements to persuade its videos. In this study which is carried out as a case study in the qualitative research design, six of the DAEŞ propaganda videos were selected with the sample sampling method and the content analysis was conducted. This data was then analyzed in comparison with popular TV series (Person of Interest), movies (American Sniper, Unthinkable), digital games (Call of Duty, Grand Theft Auto, Medal of Honor, Sniper Ghost Warrior), movie posters (The Expendables 2). The results show that DAEŞ uses anthropological data, popular culture and Hollywood effect in propaganda videos. The findings have been discussed in the context of social anthropology and tried to create a new perspective.
\end{abstract}

Keywords: Anthropology, Game, Terror, ISIS, Propaganda

\footnotetext{
* Sivas Cumhuriyet Üniversitesi

** Üsküdar Üniversitesi 


\section{Giriş}

Antropoloji insanı inceleyen bir disiplin olarak ${ }^{1}$ birçok disiplinden faydalanır. İnsanı incelemek, insan ve insana dair disiplinler arası bir yaklaşımı da mecburi olarak beraberinde getirir. Alt dallarının s1klığı nedeniyle antropoloji geniş bir yelpazede farklı bilimsel yöntemler kullanabilir. Bu bağlamda antropoloji asıl amacı olan "insanı anlamayı” değişik perspektif ve bakış açılarıyla, deneylerle araştırarak verilerini bize sunar.

Antropoloji insanı holistik bir bakış açısıyla bir bütün olarak ele alarak tüm yönlerini inceler. ${ }^{2}$ Antropolojik çalışmalar "İnsan güvenliği" kavramını merkezine alarak şiddetin ve karmaşık toplumsal olayların da analizini yaparlar. Antropoloji insan için güvenli bir çevrenin evrimsel önemine ilişkin verileri toplarken, bu güveni tehdit eden unsurların varoluş sebebini ve yine insanın bu çevreyi yok etme çabasını da anlamaya çalışır. Bu aslında insanın yine insan tarafından anlaşılmaya çalışılması başka bir ifade ile biyolojik olarak aynı donanıma sahip bir türün kendini inceleyerek idrak etme çabasıdır.

Yaşanılan coğrafya, toplum, medya, kültürel etkileşimler, inanışlar, ritüeller vb. birçok faktör insan davranışlarını o denli değiştirir ki, insan kendi türünü anlamakta zorlanır. Terör bu gerçeklerden biridir. Terör yarattığı korku iklimini teknoloji vasıtasıyla tüm dünyaya yayabilmekte ve kullandığı propaganda teknikleri ile farklı toplumlardan taraftar toplayabilmektedir. Evrensel referanslar olan arketipler bu anlamda coğrafi, sosyal, etnik, dini vb. farklılıkların yarattığı bilinç katmanını bypass ederek bilinç dışının diliyle iletişim kurmaya izin verir. Böylelikle bireylerin görünmeyen içsel kodları tetiklenerek, insan doğasındaki ilksel ve dürtüsel alan aktif hale getirilmektedir. İnanç ve eylem arasındaki bağıntı yeniden inşa edilerek orijinal kodlar işlevsizleştirilmektedir.

$\mathrm{Bu}$ çalışmada DAEŞ terör örgütünün popüler kültür unsurlarını ve sosyal antropolojik verileri teknolojik gelişmelere paralel olarak propaganda çalışmalarında ikna amacıyla nasıl ve ne şekilde kullandığının ortaya konulması amaçlanmaktadır.

Çalışmanın temel hipotezi DAEŞ'in propaganda faaliyetlerinde hedef kitlesini sosyal antropolojik kodları bilinçli biçimde kullanarak etkilediği iddiasıdır. Bu kodlar görsel materyaller içinde bazen doğrudan içeriği oluşturmakta, ama çoğu zaman sembolik düzlemde bilinçdışı çağrışımlara izin verecek teknik müdahalelerle anlatı içine gömülmektedir.

Bu araştırmada Nitel modelde yürütülmüş ve araştırmanın doğasına uygun olarak 'Durum çalışması (Case Study) deseni' kullanılmıştır. Araştırmalar-

1 English Oxford Living Dictionaries, https:/en.oxforddictionaries.com/definition/anthropology, (Erişim: 06.07.2017).

2 Gözde Dalan Polat, "İletişim Antropolojisi Üzerine Bir Deneme.” Global Media Journal: Turkish Edition, 6.12 (2016). 
da bir ya da daha fazla durumu derinlemesine inceleyerek araştırmanın soru ve konularına dikkat çekmek amacıyla Durum çalışması kullanılır. ${ }^{34}$ Bireyler, gruplar, kurumlar, kültürler vb. durum olarak nitelendirilebileceği gibi kendisine has, özgün bir şey de durum olarak nitelendirilebilir. ${ }^{5}$

Görgül bir araştırma yöntemi olan durum çalışması, çok yönlü ve derinlemesine bir inceleme yapar. ${ }^{67}$ Çalışmada ele alınan tek durum içerisinde birden fazla alt analiz birimi söz konusu olduğundan iç içe geçmiş tek durum deseni kullanılmıştır. ${ }^{8}$

Çalışmanın amacı doğrultusunda DAEŞ'in değişik internet sitelerinde yayınlanan propaganda videoları orijinal boyut ve sürelerinde bilgisayara indirilmiştir. Ardından bütün videolar iki araştırmacı tarafından birbirinden bağımsız olarak tek tek izlenmiş ve araştırmaya veri olabilecek unsurları taşıyıp, taşımadığ 1 tespit edilmiştir. Daha sonra her araştırmacının verileri birbiri ile karşılaştırılmış ve böylece veri analiz sürecinin güvenirliği test edilmiştir. Araştırmanın amacına uygun verileri sağlayan durumlar tercih edildiğinden araştırmada amaçlı örnekleme yöntemlerinden ölçüt örnekleme yöntemi ${ }^{9}$ kullanılarak videolardan 6 tanesi seçilmiştir.

Her videonun içerisinde popüler kültür öğelerinden en az birini barındırma şartı ölçüt olarak alınmıştır. Seçilen videolar araştırmacılar tarafindan tekrar izlenerek ilgili sahnelerden ekran görüntüsü alınmış, orijinal sahnelerle karşılaştııılmıştır. Alınan ekran görüntüleri ayrıca Google taraması yapılarak, oyunlar için açılmış forum sayfalarına oyuncuların yüklemiş olduğu fotoğraflarla da karşılaştırılmıştır.

DAEŞ propaganda videoları genel olarak analiz edilmiş ardından içerikler "Oyun sahneleri", "Film-dizi sahneleri" ve "Diğer sahneler" olarak üç koda ayrılmıştır. Her bulgu ayrı ayrı irdelenmiştir.

\section{Terörizmin Antropolojik Kodları}

Antropoloji alanında yapılan birçok araştırma terör ve terörist eylemlerin kültürel, ırksal, coğrafi, dini, politik, ekonomik, psikolojik vb. nedenleriyle ilgili

\footnotetext{
3 Larry B. Christensen, Johnson Burke ve Lisa Anne Turner, Araștırma yöntemleri: Desen ve Analiz (An1, 2015).

4 Ali Yıldırım ve Hasan Şimşek, Sosyal Bilimlerde Nitel Araştırma Yöntemleri, 9. Genişletilmiş Baskı, (Ankara: Seçkin Yayınevi, 2013).

5 Michael Quinn Patton, Qualitative Evaluation and Research Methods, (Thousand Oaks, CA, US: Sage Publications, Inc., 1990), 384.

6 Yıldırım ve Şimşek, Sosyal Bilimlerde Nitel Araştırma Yöntemleri, 277.

7 Patton, 384.

8 Yıldırım ve Şimşek, Sosyal Bilimlerde Nitel Araştırma Yöntemleri, 277.

9 A.g.e., Patton, 
bilgileri irdelemekte ve çözümler konusunda önerilerde bulunmaktadır. ${ }^{10} 1112$ 131415

Küreselleşme olgusu, yeni medya ve teknolojik gelişmelerle birlikte "yeni terör" ${ }^{\prime 16}$ örgütleri kendisine taraftar toplama, amaçlarını ve eylemlerini duyurma, finansman, tedarik, istihbarat toplama, dünyayı ve bölgesel farkl1lıkları daha iyi analiz etme vb. konularda çok daha etkin olmaya başlamışlardır.

Terörist organizasyonlar bu etkinliği sağlarken teknolojiyi ve medyayı da kullanmaktadırlar. Dünya geneline yayılmış olan toplumsal ilişkiler ve kilometrelerce ötede yaşanan olayların, yerel oluşumları etkileyecek derecede yoğunlaşması olarak tanımlanan ${ }^{17}$ bir küreselleşme, medyadan bağımsız olarak düşünülemez. Kazan'ında belirttiği gibi "Uluslararası terörizm ve medya arasında yıllardır tartışılan çok yönlü ilişkiler ağı bulunmaktadır”. ${ }^{18}$ Bu ilişkiler ağı haberler, programlar vb. gelen reyting ile şiddetin insan doğasındaki yapısı ve merakını birleştirerek terör örgütlerinin adeta bir marka gibi bilinirliğini arttırmaktadır.

"Karş1lkklı olarak birbirini besleyen bu ikili ilişki, bir yandan teröristlere kendilerini ve taleplerini ifade ederek popülerleşebilecekleri firsatlar sağlamakta; diğer yandan da medyanın haber açlığını giderebilecek kaynakları üretmektedir." 19

Özellikle medyanın gün içerisinde an be an takip edilebilen bir hale gelmesi, sosyal medyanın ve bu kanallardan yapılan bilgi akışının insanların tutum ve davranışlarını etkilemesi "terörün halkla ilişkileri"ni de kolaylaştırmıştır. Terör örgütü perspektifinden bakarsak "iyi bir terörist aynı zamanda iyi bir halkla ilişkilercidir” anlayışının var olduğu dahi söylenebilir.

10 Nandini Sundar, “Toward an anthropology of culpability.” American ethnologist, 31.2 (2004): 145-163.

11 Thomas Hylland Eriksen, “A darker shade of pale: Cultural intimacy in an age of terrorism", Anthropology Today, 27.5 (2011): 1-2.

12 Janine R. Wedel ve diğerleri "Toward an anthropology of public policy.", The ANNALS of the American Academy of Political and Social Science, 600.1 (2005): 30-51.

13 Jeanette Haynes Writer, "Terrorism in Native America: Interrogating the past, examining the present, and constructing a liberatory future.", Anthropology \& Education Quarterly,33.3 (2002): 317-330.

14 José Macias, “The tragedy of terrorism: Perspective, reflection, and action in the aftermath.", Anthropology \& education quarterly, 33.3 (2002): 280-282.

15 Lawrence A. Kuznar, "Rationality wars and the war on terror: Explaining terrorism and social unrest.”, American Anthropologist, 109.2 (2007): 318-329.

16 Bu ifade ilk kez 1993 yılında New York’ta bulunan Dünya Ticaret Merkezi'ne gerçekleştirilen saldırının ardından geleneksel terör eylemlerinin değiştiğini vurgulamak amacıyla kullanılmıştır.

17 Anthony Giddens, Modernity and Self Identity, Polity, (Cambridge, 1991), 21.

18 Hüseyin Kazan, “Terör-Medya İlişkisi ve Medyada Terör Haberciliği.”, Güvenlik Stratejileri Dergisi, 12.24 (2016): 110-111.

19 A.g.m., 111. 
Terörün kullandığı en önemli enstrümanı ve terörist olmaya giden yolun başı, ortası ve sonu propagandadır. ${ }^{20}$ Propagandanın da başarıya ulaşabilmesi için etkili ikna teknikleri kullanmanız ve hedef kitlenin profilini iyi analiz ederek mesajınızı güçlü sunmanız gerekir.

Terör örgütleri ve özellikle küresel çapta tehdit oluşturanları kendi yayınlarında amaçlarını ve bu amaç doğrultusunda uyguladıkları şiddeti haklı gösterebilmek ve kendilerine insan kaynağı sağlayabilmek için çeşitli yollar denerler. Bunlardan biri de antropolojik verilerdir.

Terör örgütleri korkuyu yaratmak için kullandıkları araçların içine yönlendirmeye ve ikna etmeye çalıştıkları toplumların antropolojik verilerini de ustaca işlemektedirler.

Örgüte taraftar toplamak için çekilen bir videoda veya hazırlanan bir illüstrasyonda kültürel, dilsel, coğrafik, simgesel verileri ustaca işleyebilmektedirler. Şiddetten çok daha öte olan ve barbarca diye tarif edilebilecek bir eylemde dahi coğrafi özellikleri, farklı milletlerden insanların yaşam alışkanlıklarını, tutumlarını, kültürlerini, dillerini, dinlerini, inanışlarını, eğlence, seyahat ve dinlenme tercihlerini ve hatta oyunlarını profesyonelce analiz ederek propagandalarında kullanabilmektedirler.

Terör örgütleri hızla değişen, tehditkâr ve rekabetçi bir ortamda faaliyetlerini etkili bir şekilde devam ettirebilmeleri için hızlı bir adaptasyon ve davranış değişikliği yapmaları gereklidir. ${ }^{21}$

Değişen dünyada terör örgütleri kendilerini bu dinamiklere çok çabuk adapte edebilmekte, nihai amacına ulaşmada bilimsel veriler, analizler ve teknolojiden de yararlanmaktadır.

Demir'in de belirttiği gibi terör örgütleri varlıklarını tehdit eden ve yeni firsatlar veren koşulların farkındadırlar ve örgütsel yapılarından tutun, fonksiyonlarına, söylemlerine ve eylemlerine kadar değişime giderek yeni durumlara uyum sağlayabilirler ve böylece kendilerini geliştirebilirler. ${ }^{22}$

Bu açıdan bir toplumun geçmişten gelen, hali hazırda var olan ve geleceğe ilişkin olarak taşıdığı arketip kodlar önem taşır. Bu kodlar her toplum için benzer veya farklı anlamlar içerebilir. Keza yine inanışlar, kültürel değerler ve sembolik anlamı yüksek olan çağrışımlar kitleleri harekete geçirebilir. Terör eylemlerinde hedefin halkı korku ve paniğe sevk etmesi amaçlanır. Bu amaç için insanların değer atfettiği, tarihsel, kültürel olarak önemi olan ve o top-

\footnotetext{
20 İhsan Bal, “Terör Nedir, Neden Terörist Olunur?” Terörizm: Terör, Terörizm, ve Küresel Terörle Mücadelede Ulusal ve Bölgesel Deneyimler içinde (Der.) İhsan Bal, (Ankara: USAK Yayınları, 2006) 13.

21 Cenker Korhan Demir, “Öğrenen Örgütler ve Terör Örgütleri Bağlamında PKK.”, Uluslararası Ilişkiler/International Relations, (2008): 57-88.
}

22 A.g.e., 57-88. 
lumla özdeşleşmiş simgesel noktalar özellikle seçilir. Kitleleri ikna etmede ve yönlendirmede korkunun etkisi uzun yıllardır bilinmekte ve en etkili ikna unsurlarından biri olarak kabul edilmektedir.

Terörist eylemler sembolik ifadeler yaratırlar, aynı zamanda var olanı değiştirme amacı da taşırlar. Yitzhak Rabin suikastı ya da İkiz Kuleler'e yapılan terör saldırıları bu anlamda kristalize örneklerdir. Tercih edilen dekor, izleyicilerin yoğunluğu ve sonrasında yol açacağı zincirleme reaksiyonlar dikkate alındığında, ${ }^{23}$ DAEŞ tarafından düzenlenen terör eylemlerinin de sembolik değeri açısından incelikli bir biçimde planlandığı sonucuna ulaşmak mümkündür. Nitekim Rabin suikastı sonrasında sekteye uğrayan Arap-İsrail barış süreci ve 11 Eylül sonrasında Ortadoğu'nun "Teröre karşı savaş" sloganıyla hiç olmadığı kadar istikrarsız bir periyoda girmesi uzun vadeli kurgusal bir terör vizyonunu düşündürtmektedir. Terörü çağrıştıran doğrudan ve dolaylı mesajların ideal sıklıkla farklı iletişim kanallarında yer almasıyla "dünya imajı" "terör" kavramıyla birbirine kenetlenmiş bir algıya yol açabilmektedir.

Düz anlama eşlik eden bilinçdışı bileşenler sonuç noktasında başlangıcın deklare ettiği niyetin aksi yönde oluşumlara sebebiyet verebilmektedir. Keskin ikili karşıtlıkların cisimleştiği terör olayları bir yönüyle karşıt düzlemlerin aralarındaki alanı muğlaklaştırarak, zihinsel yönelimini dağıtmaktadır. Oluşan muğlak alanda nihai manzaranın işaret ettiği meşru hedeflerin sorgulanabilmesi de zihinlerdeki "dönüşüme uğramış dünya vizyonu"nun izin verdiği ölçüde gerçekleşebilmektedir. Oyunun kuralını geri dönüşsüz olarak değiştirdiğinizde bilindik evrensel yasaların yerini alan, terörün matematiği galip gelmektedir.

Bir terör örgütünün hedeflediği kitlenin antropolojik kodları; fiziksel ve biyolojik özellikleri, coğrafi zayıflıkları, inanç sistemi, kültürel hassasiyetleri, simgeleri, sembolleri, tutum ve alışkanlıkları, geçmiş hafıza dökümü, travmaları, reaksiyon şiddeti ve reaksiyon zamanı kırılma noktalarının tahlili için hayati önem taşır.

Kırılma noktaları kişilerin, grupların veya toplumların telafisi imkânsız zararlar doğuracak sinir uçlarıdır. Bu uçlara dokunulduğunda verilecek tepkinin süresi ve şiddeti diğerlerine nazaran oldukça güçlüdür. Ancak bunların tahribatı telafisi imkânsız zararlara yol açabilecektir. Propaganda tekniklerinin iyi kullanan bir terör örgütü bu kırılma noktalarını bilir. Varlığını devam ettirebilmek ve etkinliğini arttırabilmek için bilmek zorundadır.

\section{DAEŞ Videolarının Analizi}

Hedef kitleyi ikna etme Simgeler, semboller ve çağrıştırıcı diğer unsurlar insanlara gösterilen şeyden farklı ve daha derin anlamlar verebilir. Bunlar top-

23 Mark Juergensmeyer, "Religious Terrorism as Performance Violence", The Oxford Handbook of Religion and Violence içinde (Der.) Mark Juergensmeyer, Margo Kitts ve Michael Jerryson, (New York: Oxford University Presss, 2013), 283. 
lumsal hayatın her aşamasında vardır ve ikna tekniklerinde de kullanılır.

Hepimiz dini bir simgenin bu dine inanan kişiler üzerinde nasıl bir etkisi olduğunun bilincindeyizdir. İslamiyet'in hilali, Hristiyanlığın haçı ya da Yahudiliğin Davut Yıldızı, İnkalar için güneș, Hindular için inek, Kızılderililer için beyaz bufalo buzağısı ya da herhangi bir dini tapınma nesnesi, inananlara yıllarca sürmüş mücadeleyi ya da eziyeti çağrıştırabilir ya da bir felsefeyi ya da inancı akıllara getirebilir. ${ }^{24}$

Çalışmaya kaynak teşkil edilen materyaller çözümlenirken, DAEŞ'in ikna mekanizmasını incelikli bir biçimde tanımlamak gerekmektedir. Öncelikli olarak örgütün doğrudan ve dolaylı olarak kitleler üzerinde yaratmayı hedeflediği etki ortaya konulduğunda, kullanılan sembol, simge, teknik ve mecraların işlevi netlik kazanacaktır.

DAEŞ Yahudileri, Hristiyanları, ateistleri, Rafida grubunu, mürtetleri²5, "Sahawat" (Awakenings, Sons of Iraq ${ }^{26}$ ) denilen grubu yok edilmesi gereken hedef olarak görmektedir.

DAEŞ bilinçli olarak Müslümanlarca aksi düşünülemeyecek biçim de kabul edilmiş ifadelerden yola çıkarak mesajlarını tanzim ediyor, İslamiyet'in ilk dönemlerindeki referansları sıkça kullanıyor ${ }^{27}$. Akılcı ve insani yönü güçlü ifadeleri cinayet ve tecavüz gibi eylemlere mesnet teşkil edecek biçimde kullanmaları, aslında savaştıkları şeyin ifade ettikleri gibi modern Batı ve onun yozlaşmış sisteminden başka olabileceğini düşündürüyor.

\subsubsection{Dehşet Uyandırmada Kullanılan Mecralar ve Kullanılan Teknikler:}

DAEŞ ileri teknolojinin kullanıldığı video yapımlar ve dijital oyunlar üretmektedir ${ }^{2829}$. Konvansiyonel iletişim ortamlarının yanında, sosyal medya etkin olarak kullanılmakta, kontrol ve sansür mekanizmalarının işletilemediği

24 William A Haviland, Harald E.L. Prins, Dana Walrath ve McBride Bunny. Kültürel Antropoloji. Çev. İnan Deniz Erguvan Sarığlu, İstanbul: Kaknüs Yayınları, 2008, s.116.

25 Sünni olmayanların tümü kastedilerek dinden çıkmış kabul edilmektedir.

26 Amerika’nın El Kaide’ye karşı örgütlediği yapı "Proxy Wars” (Vekâlet Savaşları) açısından değerlendirilebilecek bir durum. Dostumun düşmanı düşmanımdır mantığı bir süre sonra yerini vekillerin özerkleşmesine ve kaotik bir biçimde hareket etmesine bırakıyor. Orta Doğu'daki dinamikleri çözümleyebilmek için kabileler arası inanç ve gündelik yaşam pratikleri açısından ortaya çıkmış olan farklılıklar, bu tür silahlı güçlerin motivasyonları konusunda öngörüde bulunabilmede önem teşkil etmektedir.

27 Graeme Wood, What ISIS Really Wants, The Atlantic, March 2015, https:/www.theatlantic.com/ magazine/archive/2015/03/what-DAEŞ-really-wants/384980/, (Erişim: 03.09.2017).

28 Ahmed Al-Rawi, "Video Games, Terrorism, and ISIS's Jihad 3.0", Terrorism and Political Violence 30, No: 4 (2018), 746 https://www.tandfonline.com/doi/pdf/10.1080/09546553.2016.1207633?needA ccess=true, (Erişim: 20.07.2018).

29 Linkte Saleel Al-Sawarim isimli oyundan alınan video kayıt yer almaktadır https://www.youtube. com/watch?v=VjFzkx2q5uY, (Erişim: 20.07.2018). 
ve aynı zamanda içeriklerin indirilerek offline olarak da istifade edilebildiği sistemler üzerinden hedef kitlelerine ulaşmaktadır. İçeriklerde kafa kesme, diri diri yakma, köleleştirme, tecavüz, aşağılama, şiddeti meşru kılmak için belli kriterler sağlandığında hedefi insan olarak kabul etmeme, karş1 saftaki insanlara zararlı ve yok edilmesi gereken bir hayvan ya da bir nesne muamelesi yapma siklikla tercih edilmektedir.

Burada Zulaika'nın tespitleri önemlidir:

Masallar, avlanma veya savaş gibi ritüelleşmiş bağlamlarda, insan ve insan olmayan, uygar ve barbar arasında kategorik belirteçler haline gelen, böylece insan gibi kültürel olarak tanımlanan bir düzeni tehdit eden her şeyin ortadan kaldırılmasına izin veren hayvansal metaforları kullanma eğilimindedirler. Cinayeti açıklamanın bir yolu yok. Tek yapabileceğimiz, onu kavramsallaştırmak için tarihsel ve kültürel modeller sunmak. Vico'nun tavsiyelerini takiben, kültürel antropoloji, etnografik olarak ritüel metaforlara ve kafa avc1lığ1 ya da "ilahi akrabalık" gibi kültürel kurumların altında yatan efsanevi yapılara odaklandı. Fakat antropolojinin bu paradigmayı - kafa avcılarına, kral katillerine, askeri kahramanlara ve diğer ritüelleştirilmiş cinayetlere - tabulaştırılmış "teröristlere" uygulayabilmesine izin vermesi mümkün mü? Teröristler bizden tamamen farklı mı yoksa sonunda teröristler ve terörle mücadele edenler de aynı insanlık alanına $\mathrm{m}$ aitler? ${ }^{30}$

\subsubsection{Hedefte Yaratılmak İstenen Algıdaki Anahtar Kavramlar:}

"We will burn America", "Evinde yok etme" (İkiz kule görsellerini videolarda anlatıyı destekleyici unsur olarak kullanma); "İkonoklazm" (Videolarda Amerikan kahramanlık sembolü olan itfaiyecileri zavallı ve çaresiz konumda gösterme), "Olay ve fenomeni özdeş kabul ettirme", "Algılara kaynak teşkil eden zemini değiştirme" (Sembollerin orijinal anlam ve düşünce setini dağıtma, kavram ve olguları tarihsel bağlamından koparma, sembol ve kavramlar arasında yeni bağlantılar kurma - Tarihi dekor ve coşkulu seyirci kalabalığ önünde toplu infaz, infazın çocuk DAEŞ militanları tarafindan gerçekleştirilmesi), "Anlam ve aidiyet arayışı içinde olanlara yeni alternatifler sunma" (Refah seviyesi yüksek batı bölgelerinden militan toplamada kullanılan mesajlar; batının kodlarıyla batıyı vurmak, kitleyi olduğu haliyle yakalayıp uygun kanaatleri inşa etmek için işlemek, bilme-tanıma-anlamlandırma-inanma-mensubu olma gibi kavramlar arasındaki sınıı muğlaklaşııma), "Oyunun kuralını değiştirme" olarak sıralanabilir. ${ }^{31}$

30 Joseba Zulaika, "Mythologies of Terror: Fantasy and Self-Fulfilling Prophecy in U.S. Counterterrorism." Kroeber Anthropological Society, 102(1), s. 6.

31 Umberto Bacchi, "Isis propaganda threatens new 9/11 in We Will Burn America video", International Business Times, 13 Nisan 2015. https://www.ibtimes.co.uk/isis-propaganda-threatens-new-9-11we-will-burn-america-video-1496096, (Erişim: 05.09.2017). 


\subsubsection{Kendi Kontrol Alanlarındakilerle Kurdukları İletişimin Kodları:}

Hâkimiyet bölgelerinde asayişi sağlamada alınan sıkı tedbirler ve caydırıcı yaptırımlar uygulanmaktadır. Kontrol altındakilerden bireysellik yerine hilafetin ortak kazanımlarına odaklanmaları istenmektedir. Dava kavramı, anlamlı bir bütünün parçası olma, o bütün ile anlam kazanma özellikle vurgulanmaktadır. İçsel değerler ve bağlantı mekanizmalarını sağlamlaştırıcı bileşenler kullanılmaktadır.

\subsubsection{Genel Algıya ve Potansiyel DAEŞ Militanlarına Yönelik Mesajlar:}

DAEŞ'in siber ortamdaki propaganda faaliyetlerinde sanal ulus kavramı, hâkimiyet alanının muğlaklığı, sisteme karşı, sistemin araçlarının kullanımı, sonraki hamlenin kestirilmesini güçleştirecek kaotik stratejiler sıklıkla yer almaktadır. Özellikle İslamiyet'in ilk dönemlerine ve tartışmasız kabul edilecek esaslarına gönderme yapılarak İslam ile ilgili kavram, olgu ve olaylar çarpıtılmaktadır. Tek yönlü bilet kullanımı yine DAEŞ'in hedef kitlesine verdiği önemli bir mesajdır. Dünyanın farklı bölgelerinden DAEŞ saflarında savaşmak için yola çıkanlar dönüş bileti almamakta, böylelikle kendileri ve aileleri için geri dönüşü olmayan bir sürece dâhil olduklarını ifade etmekteler. Pasaport yakmak da benzer biçimde hilafet dışında herhangi bir iktidar odağı ya da aidiyet kabul edilmediğini deklare etmek için kullanılmaktadır. Çekilen özel videolarda pasaportların yakılması devrimci bir ritüel biçiminde görselleştirilmektedir.

\subsubsection{Bireylerin Bilinçdışındaki Kahraman Arketipini Tetikleme:}

DAEŞ'in eylemlerini bir macera atmosferi biçiminde sunarak, örgüte dâhil olmanın insanın karşısına ömrü boyunca sadece bir kez çıkacak bir firsat olarak algılanması hedeflenmektedir. ${ }^{32}$ Videolarda yer alan kişilere karizmatik nitelikler yüklenmesi özellikle genç hedef kitlede özdeşleşim sağlamayı kolaylaştırıc1 etkide bulunmaktadır.

\subsection{Oyun Sahneleri}

DAEŞ insan doğasındaki ilksel kodlara referans vererek oyun sahnelerini çağrıştıran görsel materyalleri kullanmaktadır. İkna yöntemi olarak oyun vizyonunun tercih edilmesi aslında terör örgütünün kullandığı stratejinin ardında antropoloji ve psikoloji formasyonu olan ciddi bir uzman kadrosunun bulunduğunu düşündürtmektedir.

Oyun kavramının ilk bakışta naif ve gayrı ciddi bir anlamı çağrıştırması onun nihai eylemlerimizin ardındaki itici gücü barındırdığı gerçeğini çoğu zaman gizler. DAEŞ'in oyun kavramını kullanmasının önemini 1944 yılında

\footnotetext{
32 Imran Awan, "Cyber-extremism: Isis and the power of social media", Society 54, No.2 (2017): 139,https:/www.springerprofessional.de/en/cyber-extremism-isis-and-the-power-of-socialmedia/12144602?fulltextView=true, (Erişim: 03.07.2017).
} 
Homo Ludens isimli eserinde oyunun kültürel işlevlerini ortaya koyan Johan Huizinga'ya referans vererek anlatmak faydalı olabilir.

"Oyunun özünü oluşturan aktif ilkeyi "içgüdü "olarak adlandırırsak, hiçbir şeyi açıklamayız; eğer buna" akıl "veya" irade" diyorsak, çok fazla şey söyleriz. Ancak oyunun bir anlamı olduğu gerçeğini, şeyin kendisinin doğasında, maddi olmayan bir kaliteye işaret ettiğini kabul edebiliriz." ${ }^{33}$

Oyun ödüllendirme mekanizması ile zihni şekillendirmede ve onu farklı bir dünyaya yönlendirmede etkili bir araçtır. Bu araç arketip kodlarla çok daha etkili bir hale getirilebilir.

"İnsan toplumunun büyük arketipik aktivitelerinin hepsi oyunun başlangıcından sonuna kadar uzanır. Örneğin dili kullanma insanın iletişim kurması, öğretmesi, komuta etmesi için şekillendirdiği ilk ve yüce araçtır... Her soyut ifadenin ardında, metaforların en cesuru vardır ve her metafor kelimeler üzerine bir oyundur. Böylece insana hayatı ifade etmek için doğanın dünyasının yanında ikinci bir şiirsel dünya yaratır." ${ }^{34}$

Oyun içinde gerçekliğin bir replikasını yaratan çocuk onu anlamlandırmayı ve ona nüfuz etmeyi öğrenir. Bu öğrenme süreci pekiştirilip, tekrar ettikçe gerçek hayat ile dijital hayat arasındaki eşik olan "Gerçeklik Eşiği" aşınmaya ve bir müddet sonra birbirinin yerine geçmeye başlar. ${ }^{35}$

"Çocuk ve hayvan oyun oynamaktan zevk aldıkları için oynar ve içinde elbette kendi özgürlükleri yatar." ${ }^{36}$ Huizinga burada oyun deneyiminin özgürlük çağrıştırmasını vurguluyor. Çocuk özgür biçimde gerçekliği oyun pratiği içinde anlamlandırmayı öğrenir. Bunda bir sorun yoktur. Yetişkin ya da yetişkinliğe adım atmakta olan birey gerçekliğin ağırlığı ve zorunlulukların çevrelediği ortamdan kaçmak için oyuna yönelirken aynı zamanda özgür ve sorumsuz olduğu özellikle 0-6 yaş dönemini bilinçdışı düzlemde yeniden deneyimler. Bu dönemde eylem rasyonellikten ziyade dürtüselliğe dayanmaktadır. Bu durumun bir çocuk için pozitif işlevselliği vardır. Ancak özellikle 0-6 yaş dönemine ait bilinçdışı kodların özelliklere yetişkinlere yönelik oyunlarda kullanımı, içinde sadece duygusal anlamda serbest zaman içinde bir rahatlama alanını değil aynı zamanda irrasyonel eylemin tetikleyicisi olma potansiyelini de barındırır.

33 Johan Huizinga. Homo Ludens A Study of the Play-Element in Culture, (London: Routledge \& Kegan Paul, 1980), 1.

34 A.g.e., 4.

35 Sefer Darıcı, "Dijital Oyunlarda Kullanılan Sublımınal Mesajların Gerçeklik Algısı Üzerindeki Etkilerine Yönelik Bir Çalışma: Gerçeklik Eşiği Kavramı”, Electronic Turkish Studies 10.14 (2015).

36 A.g.e., 8 
DAEŞ'in potansiyel militanlara yönelik mesajlarını tasarlarken oyun pratiği içindeki önemli bir aşama olan inisiyasyon deneyimini kullandığını görmekteyiz. Özel ve anlamlı bir bütünün parçası olma, farklı bir aidiyet ortamını deneyimleme isteği içinde olan bu kişiler, tatmin edilmeyi bekleyen duygusal boşluklarından istifade edilerek çembere dâhil edilirler. Burada insan doğasında gerçeklik deneyiminin, onu anlamlandırma ve kontrol altına almayla ilgili istencin bir görünümü olan, beden ve ruh, fikir ve eylem gibi ikili karşıtlıkların temelini oluşturan çok önemli bir antropolojik gerçek yatmaktadır." ${ }^{37}$

Yaşamın içindeki anlamı keşfetmek ya da var olmayan anlamı bir fantezi evreni yaratarak oluşturmaya dayanan felsefi ve ideolojik açıdan önemli olan bu sorunsal, oyunun çocuk ve yetişkin için taşıdığ 1 anlam ve işlevine işaret etmektedir. Daha önce de bahsedildiği gibi çocuk var olan gerçekliği anlamlandırmak, ona nüfuz etmek, gerçek dünyaya dâhil olmak için oyun oynar. Ergen ya da yetişkinlerin oyunla ilgili motivasyonlarının temelinde ise gerçekliğin ağırlığından kaçmak ve tatmin edilemeyen anlam arayışını gidermek üzere yeni bir gerçeklik formu inşa etmek yatar.

DAEŞ propaganda videolarının birçoğunda toplumsal hafızada kolektif bir geçmiş hissi yaratan ikonları ortadan kaldırarak yeniden inşa için uygun bir zemin hazırlamaktadır. Örneğin Şekil 1'de görseli yer alan, 2015'te Antik Roma'nın Palmyra harabeleri önünde çocuk militanlarca gerçekleştirilen toplu infaz, üzerinde uzlaşmaya varılmış pek çok kodu geçersiz kılmaktadır.

İnfaz coşkulu bir kalabalık önünde, farklı kamera açılarından estetik bir formda verilirken ritus etkisi doruğa çıkmaktadır. Ama burada önemli olan arka plandaki mitos kısmıdır.

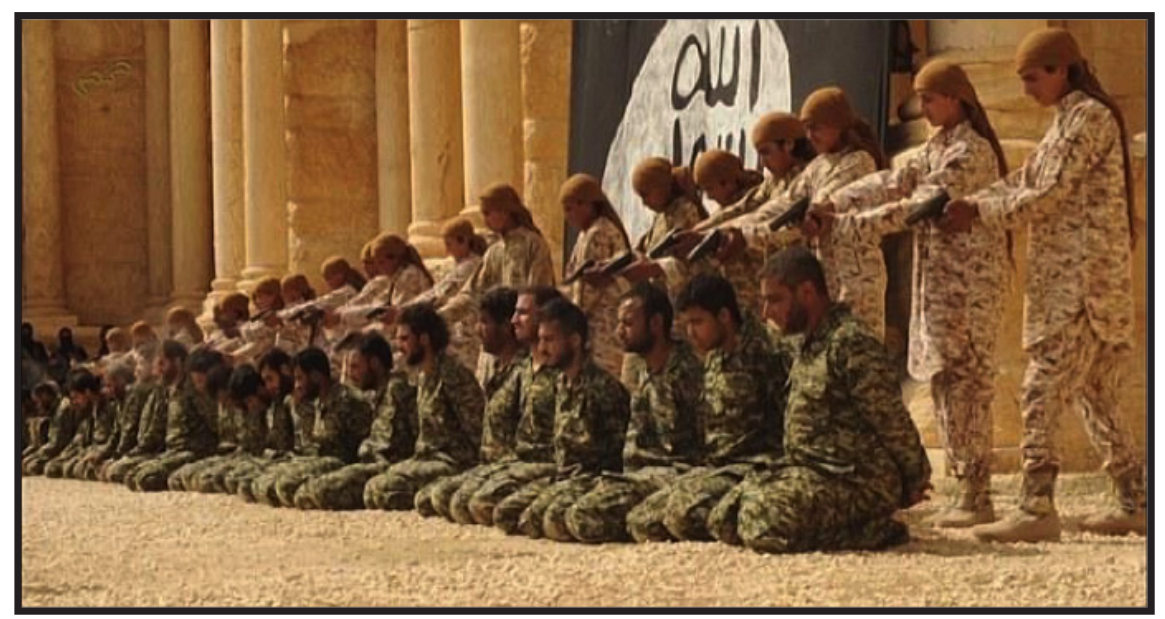

Şekil 1: Palmyra Harabeleri'nde infaz anı

37 Huizinga, Homo Ludens, 5. 
Video içindeki göstergelere baktığımızda çocuk masumiyeti, çocuk oyunu gibi yerleşik kuralın tersyüz edildiğini görmekteyiz. Videoda çocuklar askeri kostümler içinde çok sayıda yetişkini infaz etmektedir. Çocuğun nesne ve özne ilişkisi açısından oyun döneminde suç sayılamayacak sembolik kurban etme ritüelleri burada gerçek infazla yer değiştirmiştir. Oyuncak nesneler gerçek silahlar ve canlı bedenlerle yer değiştirmiştir.

Bütün bu vahşete dekor oluşturan Palmyra harabeleri de yenilenmiş bir kurguyla tarihsel bağlamından incelikli bir biçimde koparılmış, tarihin kodlarıyla da oynanmıştır. Daha sonra Pamlyra antik kenti DAEŞ tarafından tahrip edilerek mekâna ait antropolojik veriler incelikli biçimde ortadan kaldırılmıştır. ${ }^{38}$

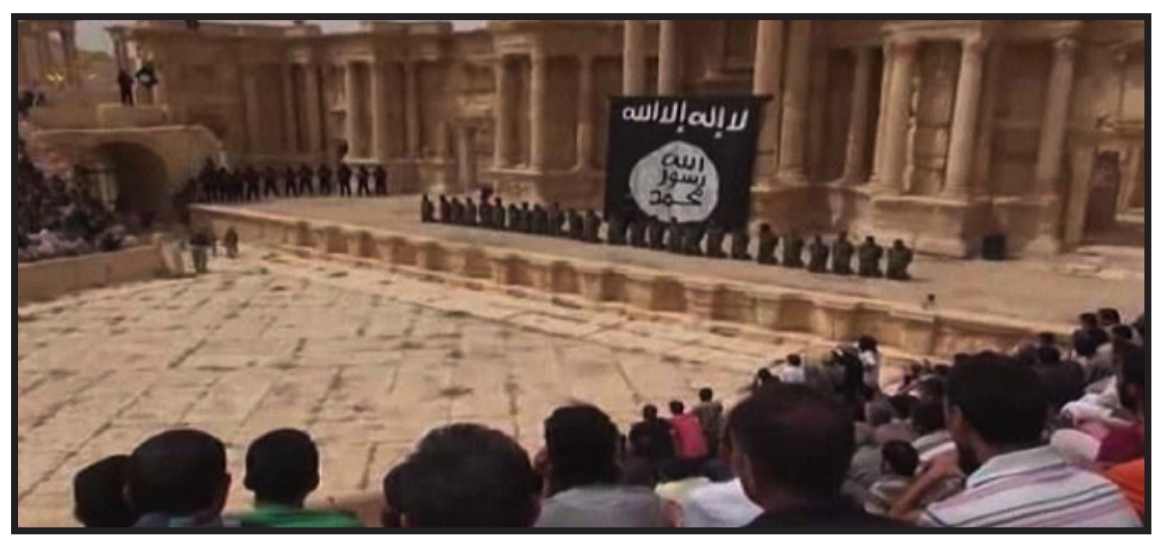

Şekil 2: Palmyra Harabeleri'nde infazı bekleyen seyirciler

Eylemi meşrulaştırmada coşkulu kalabalığın onayı ve tanıklığı önemli bir yer tutmaktadır. Antik çağdaki kurban seremonilerini çağrıştıran sahne düzenlemesi aynı zamanda karar ve uygulama alanı açısından kapalı bir sistemi de kurmaktadır. Sistemin, kuralın ve egemenliğin sembolü DAEŞ bayrağı infazın fonunu oluşturarak "devlet" kavramının kurucu bileșenlerini tamamlamaktadır. Terör kavramı ve meşru devletin tasarrufu arasındaki sınır da böylelikle buharlaştırılmıştır.

Oyun görsellerinde ve gerçek görüntülerde silahı taşıyanın bakış açısının özdeş seçilmesi oyun ve gerçeklik arasındaki algısal farkı ortadan kaldırmayı hedeflemektedir. Özellikle canlı hedefin yok edilmesiyle ilgili oyun görselleri ve gerçek görüntülerdeki benzerlikler, ortadan kaldırılanın insandan çok hayvan ya gereksiz bir nesne olduğu izlenimini vermektedir. Ufuk çizgisinin bilinçli olarak eğimli tercih edilişi hareket hali illüzyonu yaratmaktadır. Böylelikle görsele maruz kalan kişi aksiyonun içine daha rahat çekilmektedir.

38 Palmyra Harabeleri DAEŞ tarafindan 26 Aralık 2016 ve 10 Ocak 2016 tarihlerinde tahrip edilmiştir. https://www.theguardian.com/world/2017/jan/20/isis-destroys-tetrapylon-monument-palmyra-syria, (Erişim: 20.07.2018). 

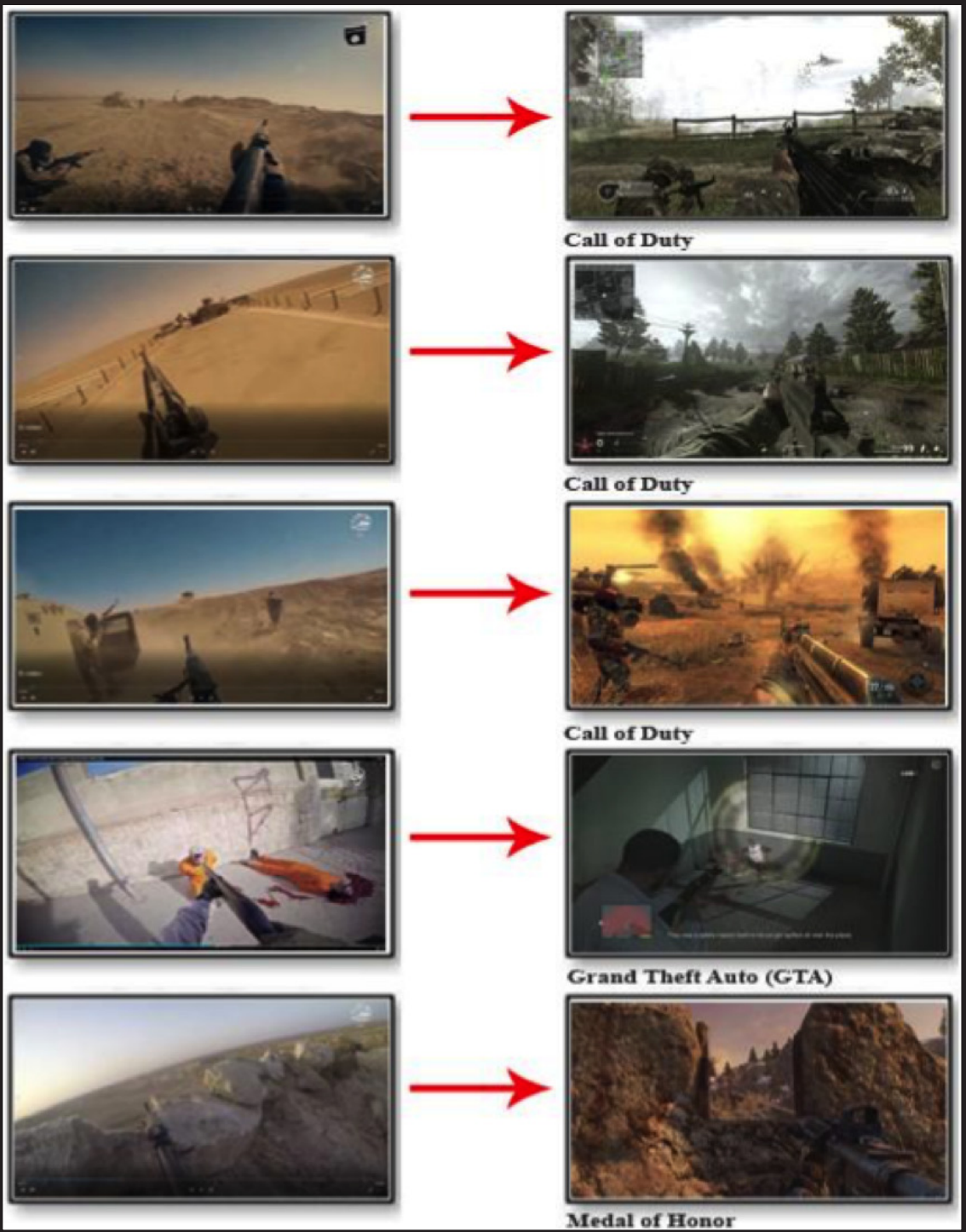

Şekil 3a: DAEŞ propaganda videoları ve popüler oyun sahneleri arasındaki ilişki

Askeri teçhizat detaylı ve estetik kurallara göre kadraja yerleştirilmiş ve böylelikle bu nesnelerin fetiş işlevi görecek biçimde algılanması sağlanmıştır.

Gasp suçunu işleyenle özdeşleşilen bir video oyunundaki açıların seçildiği örnekte öldüren özne hareket halindedir, korunaklı ve erişilmezdir, avlayıp kaçar. 
DAEŞ Videolarındaki Gerçek Görüntüler

Popüler Oyunlardan Çağrıştırılan Sahneler
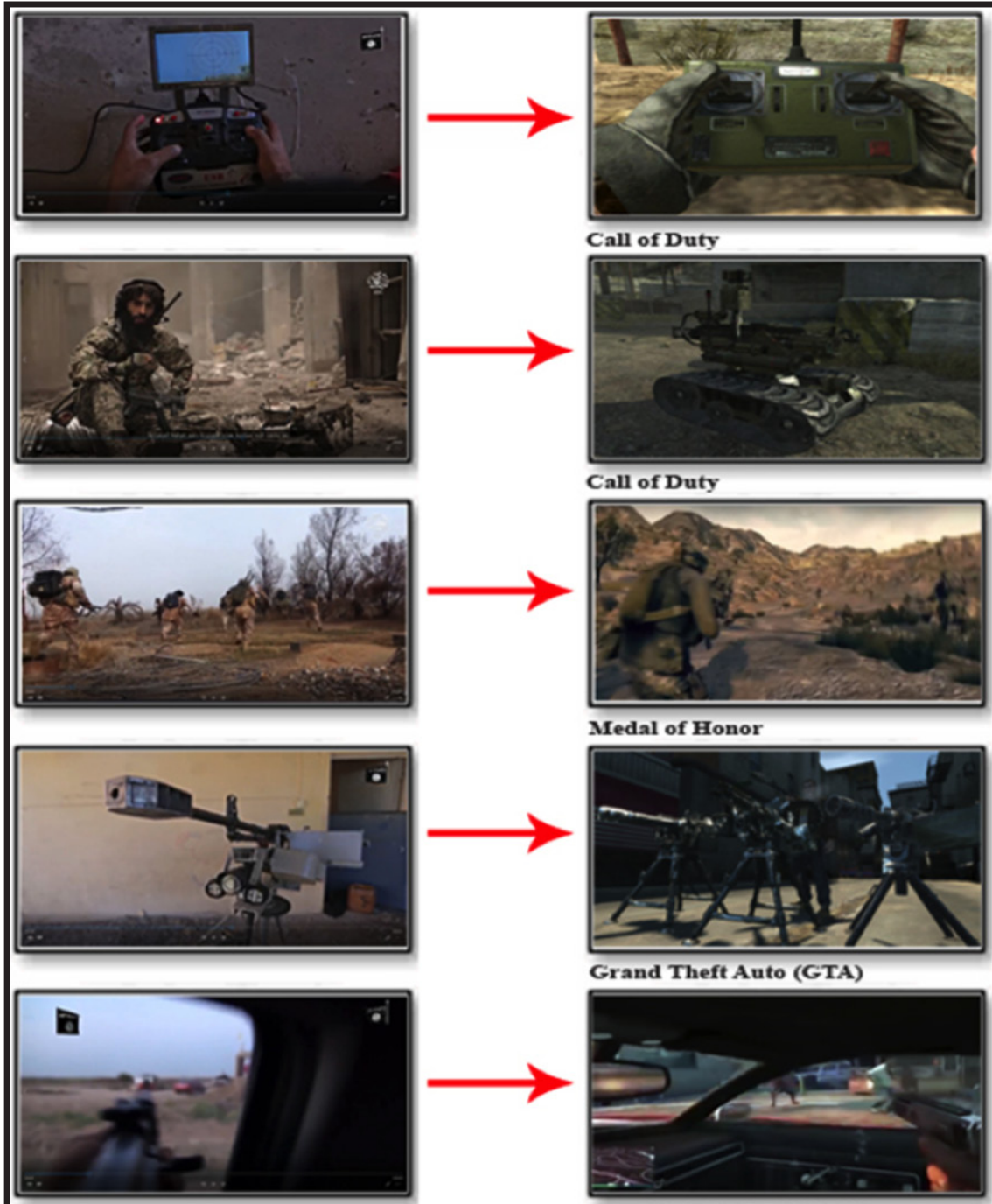

Grand Theft Auto (GTA)

Şekil 3b: DAEŞ propaganda videoları ve popüler oyun sahneleri arasındaki ilişki 
DAEȘ Videolarındaki Gerçek Görüntüler
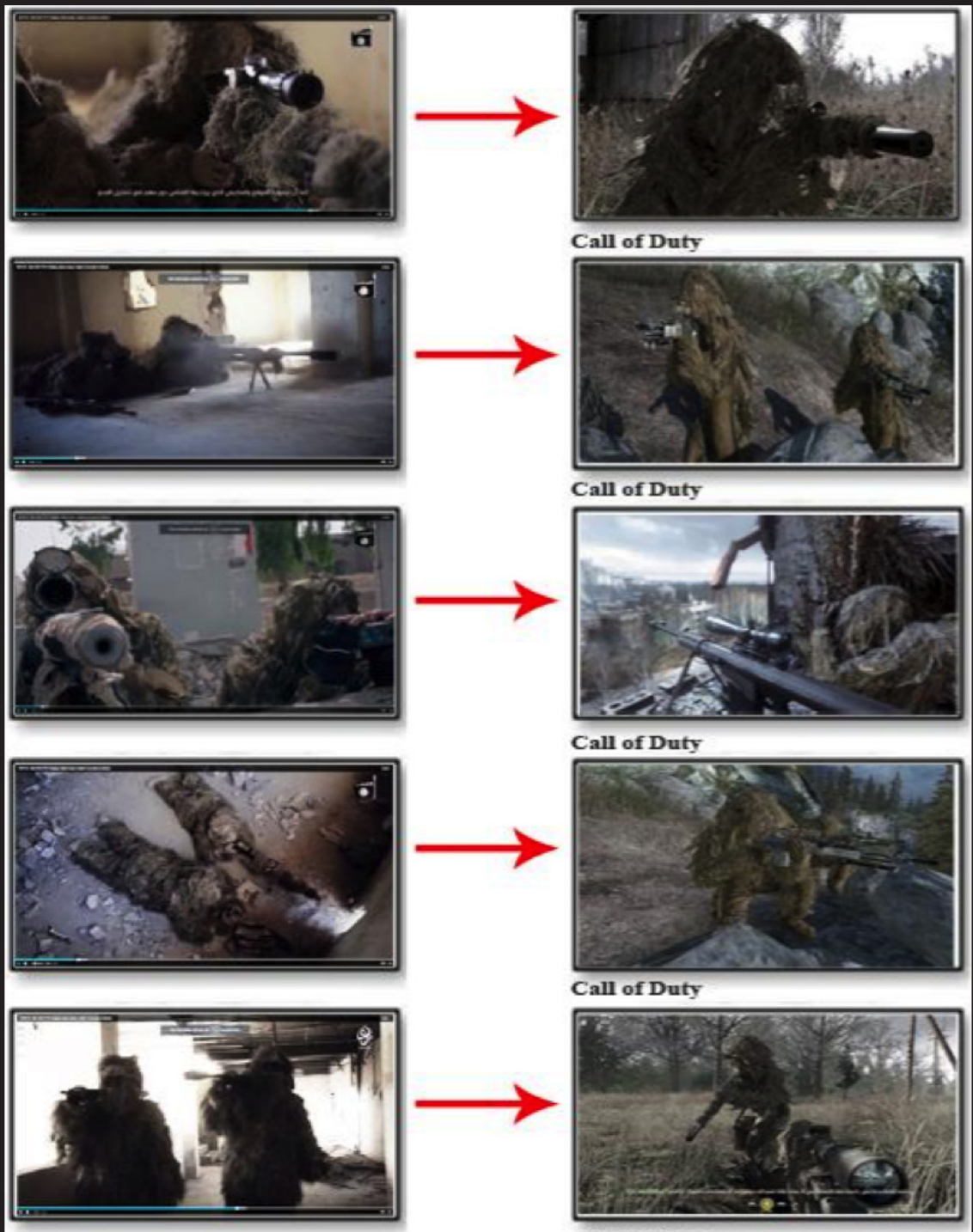

Call of Duty

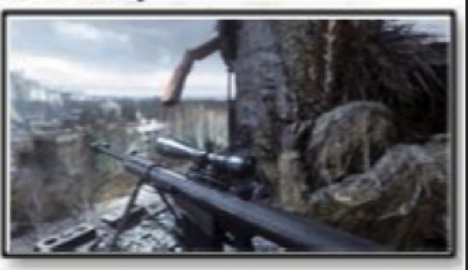

Call of Duty

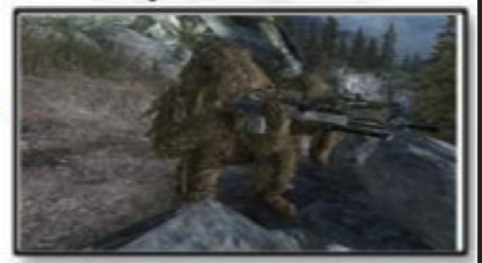

Call of Duty

Popüler Oyunlardan Çağrıştırılan Sahneler

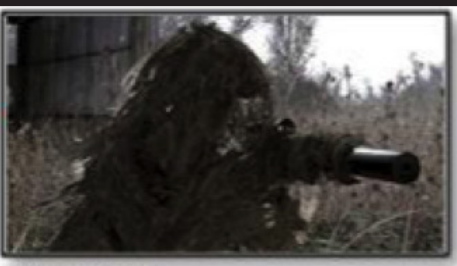

Call of Duty

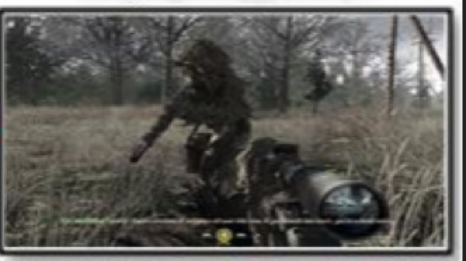

Call of Duty

Şekil 3c: DAEŞ propaganda videoları ve popüler oyun sahneleri arasındaki ilişski

Bu videolar "Mujatweets" adlı bir dizinin bir parçasıdır ve yüksek kaliteli HD görüntülerdir. İngiliz DAEŞ savaşçılarından biri olan Abu Summayyah AlBritani Suriye»nin kuzeybatısındaki bir internet kafesinden yaptığg konuşmasında çatışmanın doğasını ayrıntılı olarak anlatırken şöyle diyor: "Rejimi geri çekmede bugüne kadar başarılı olduk" ve "Suriyède savaşmak, Call of Duty oynamaktan daha iyi." 39

39 Lucas, S. 2014. “Syria Interview: Islamic's State of Iraq's Abu Summayah al Britani on Conflict and Caliphate", http://eaworldview.com/2014/06/syria-interview-islamic-state-of-iraq-abu-sumayyah-albritani-conflict-caliphate/'den aktaran Awan, Cyber-Extremism: ISIS and the Power of Social Media, 139. 
DAEŞ Videolarındaki Gerçek Görüntüler Popüler Oyunlardan Çağrıștırılan Sahneler
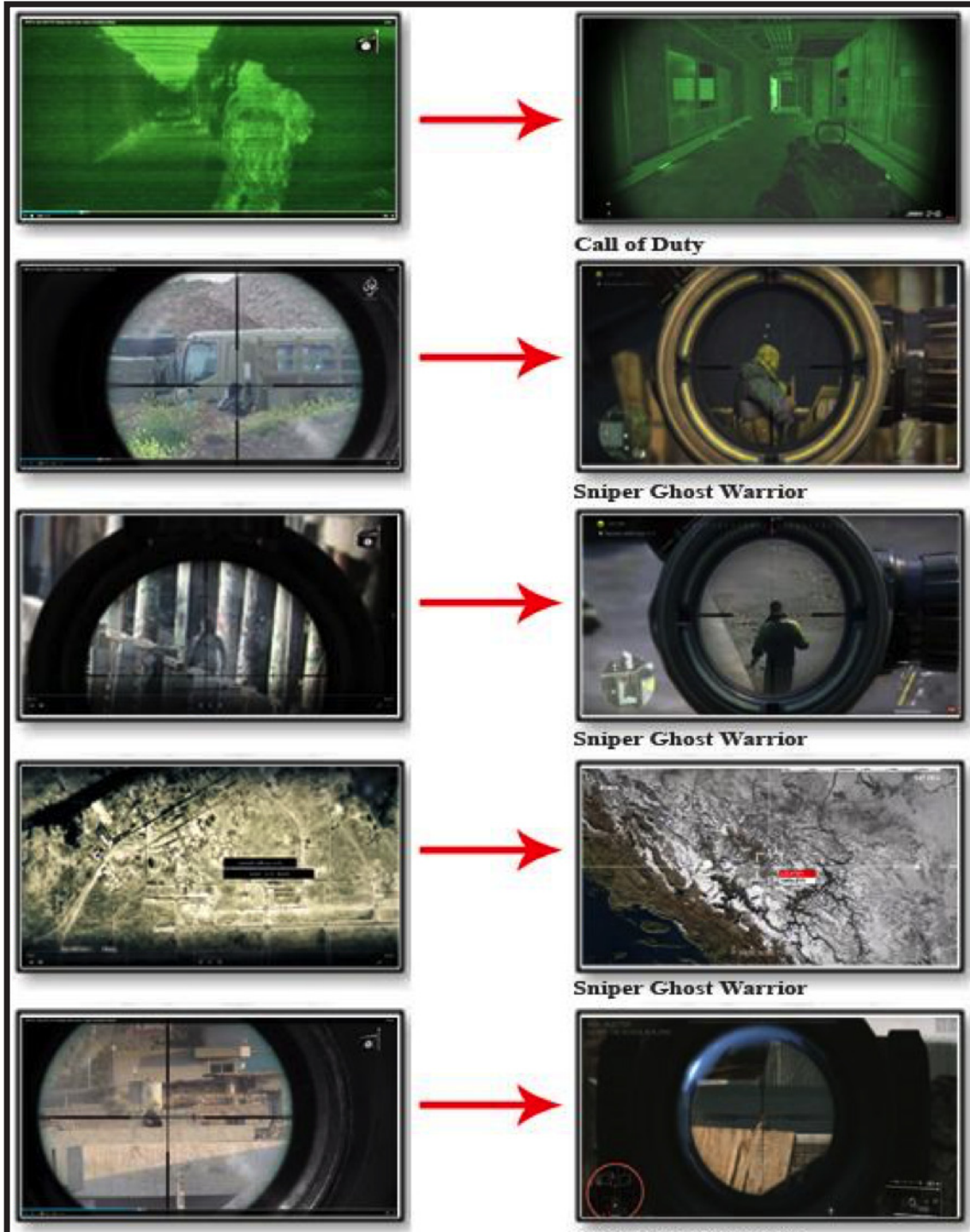

Sniper Ghost Warrior

Şekil 3d: DAEŞ propaganda videoları ve popüler oyun sahneleri arasındaki ilişsi

Kamuflaj yeteneği kazandıran kostümler ile uzak mesafeden ve gece görüş̧ özellikli gözlem ve imha görüntüleri, hem kullanılan ekipmana hâkimiyeti hem de görünmeden görme özelliğiyle tanrısal otoriteyi simgelemektedir. 


\subsection{Film-Dizi sahneleri}

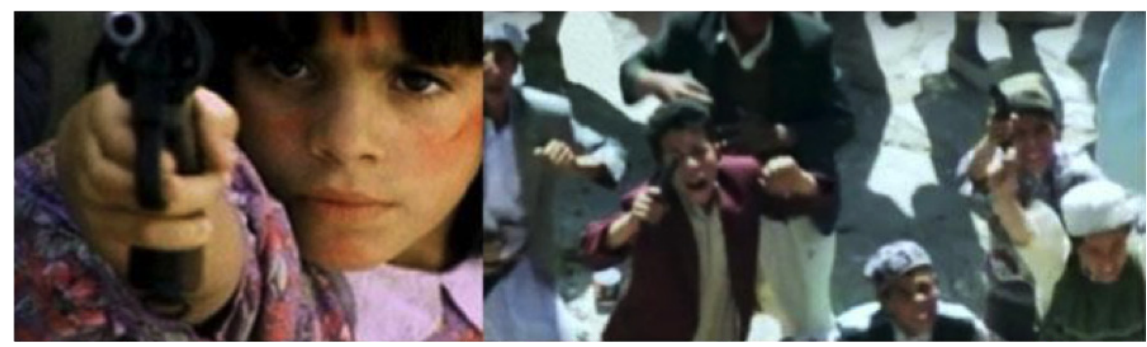

Şekil 4: Rules of Engagement, 2000

DAEŞ'in oyun pratiklerini ikna stratejileri geliştirmede nasıl kullandığını açıklarken kullanılan Palmyra'daki infazın oldukça benzer bir örneğini William Friedkin'in 2000 yılında çektiği Rules of Engagement isimli Hollywood yapımı filmde görmekteyiz.

Filmde Amerikalı subayın aralarında kadın ve çocukların olduğu çok sayıda sivilin Amerikan elçiliği önünde katledilmesi emrini vermesiyle ilgili kurgusal bir mahkemeyi konu almaktadır. Filmin sonunda Müslüman teröristlerden emir alan çocuklar Amerikan askerleri üzerine ateş açmaktadır. ${ }^{40}$

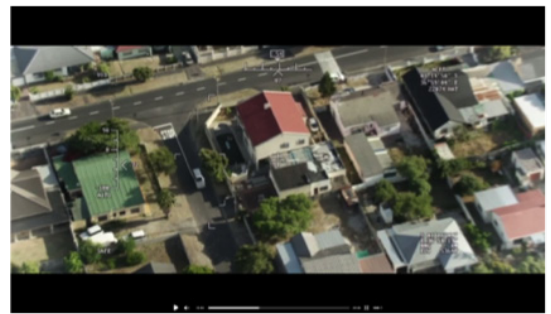

Şekil 5: Unthinkable filminden bir sahne

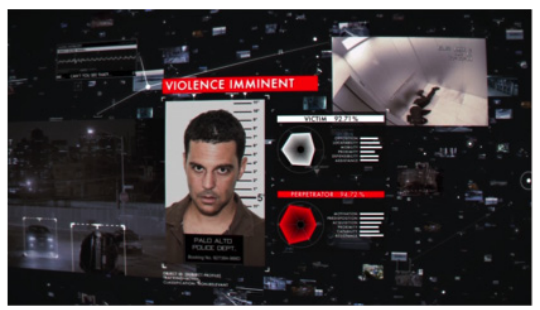

Şekil 7: Person of Interest dizisinden bir sahne

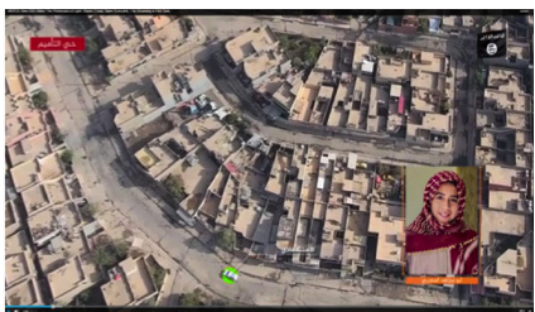

Şekil 6: DAEŞ propaganda filminden bir sahne

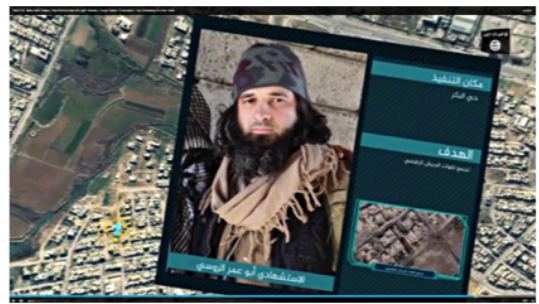

Şekil 8: DAEŞ propaganda filminden bir sahne

Peter Woodward'ın 2010 yılında çektiği Unthinkable adlı filmle benzer bazı sahnelerin de DAEŞ propagandasında kullanıldığı görülmektedir.

40 Kinda Youssef, "ISIS From the dark fiction of Hollywood", Re-visiones 5 (2015), 9. 


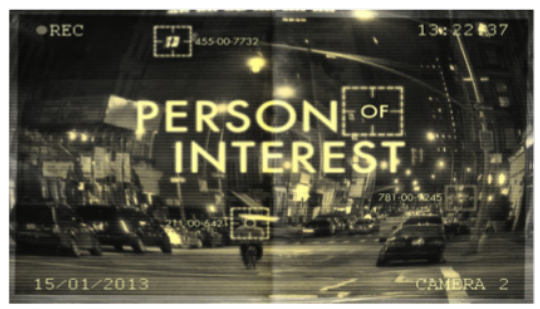

Şekil 9: Person of Interest dizisinden bir sahne

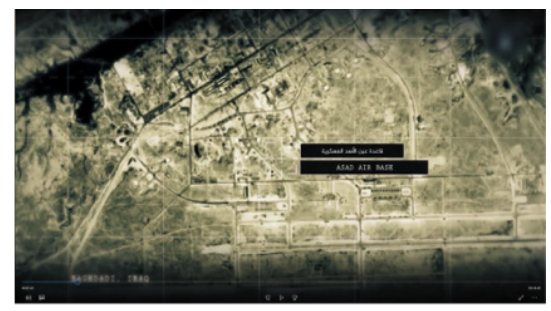

Şekil 10: DAEŞ propaganda filminden bir sahne

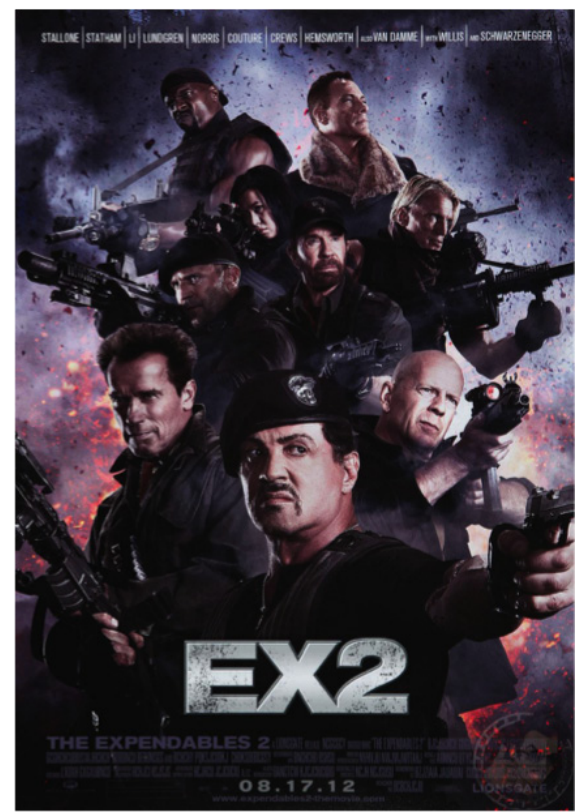

Şekil 11: The Expendables 2 film afişi

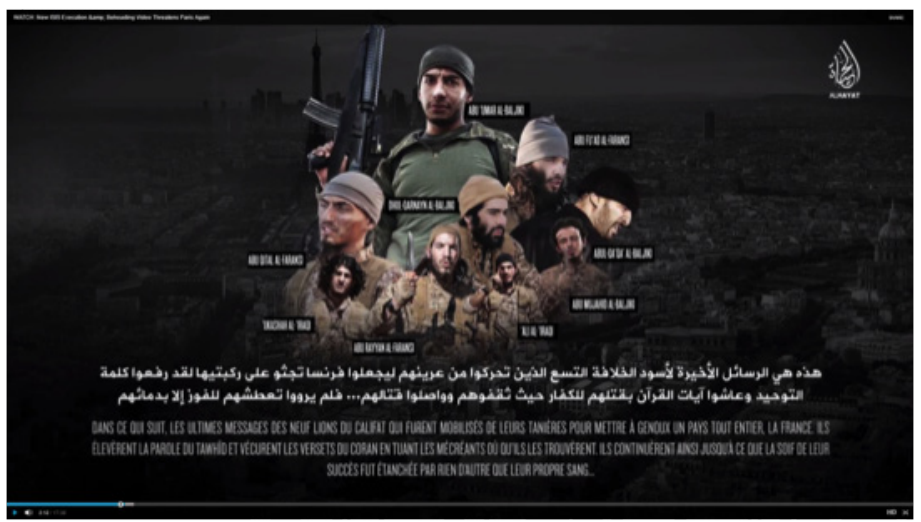

Şekil 12: DAEŞ propaganda filminden bir sahne 
Şekil 12'de görseli verilen propaganda videosu ${ }^{41}$ ile The Expendables 2 film afişi arasında benzerlikler bulunmaktadır. Videoya ait görselin fonunda Paris Champs-Élysées yer almaktadır. 13 Kasım 2015 'te DAEŞ tarafından düzenlenen ve 130 kişinin katledildiği Paris saldırısı böylelikle bir kahramanlık miti olarak görselleştirilmiştir.

\subsection{Diğer sahneler}

3.4.1. Pasaport yakma: Şekil 13'te kamuflaj giysili çocuklar DAEŞ'e aidiyetlerini pasaport yakma töreniyle ifade ediyorlar. Bu eylem DAEŞ dışındaki her türlü aidiyet ve egemenlik ilişkisini devre dışı bıraktıklarını, geri dönüşsüz bir yola girdiklerini anlatmaktadır. Geçmişle tüm bağı ortadan kaldırmak bireylerin eylemlerini DAEŞ tarafından sağlanan yeni değer sistemlerine dayandırmalarını ve böylelikle itaat etmelerini kolaylaştıracaktır. ${ }^{42}$

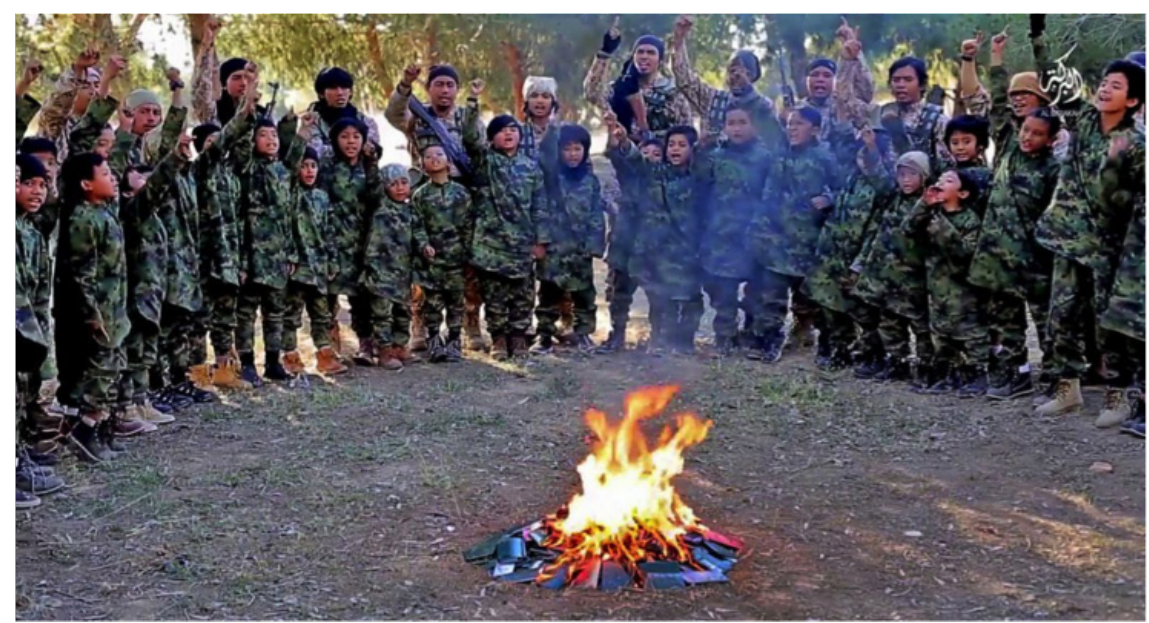

Şekil 13: Pasaport yakma

3.4.2. Baş Keserek İnfaz: Antropolojik açıdan en önemli etkileme yöntemlerinden biri de başın gövdeden ayrılmasıyla gerçekleşen infaz sahneleridir.

2012 yılında ISIS tarafından kaçırılan Amerikalı gazeteci James Foley'in infazına ait görüntüler Ağustos 2014'te son derece sistemli olarak medyaya servis edilmiştir. Videoda ABD'nın bölgedeki faaliyetlerine son verilmezse diğer bir Amerikalı gazeteci Steven Joel Sotloff'un da infaz edileceği belirtilir. ${ }^{43}$ Daha sonra Sotloff'un infazına ait görüntüler de yayınlanır.

41 "Islamic State video purports to show Paris attackers, threatens Britain", The Sudburystar, 24 Ocak 2016, http://www.thesudburystar.com/2016/01/24/islamic-state-video-purports-to-show-parisattackers-threatens-britain, (Erişim: 04.09.2017).

42 Kelly NG. "ISIS video shows terror battle is about winning young hearts, minds" Today, 23 Mayis 2016, http://www.todayonline.com/singapore/ISIS-video-shows-terror-battle-about-winning-younghearts-minds-eng-hen, (Erişim: 04.09.2017).

43 https://www.bostonglobe.com/ideas/2014/11/01/why-beheading-ultimate-tyranny/ Z7MH52cVtwYSjsmS8G32MJ/story.html, (Erişim 15.05.2014). 


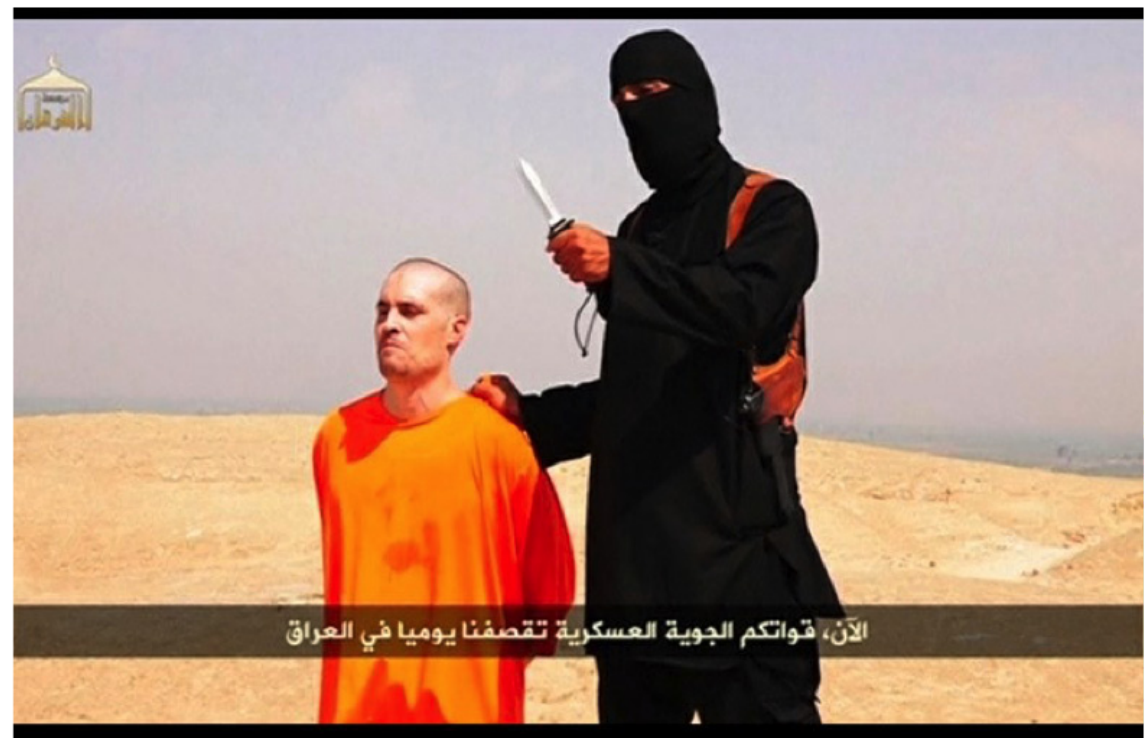

Şekil 14: DAEŞ propaganda filminde James Foley'in infaz görüntüsü

Antropolog Frances Larson başın kesilerek gerçekleştirildiği infazlara dair araştırmasının yer aldığı "Severed: A History of Heads Lost and Heads Found" adlı eserinde bu tür eylemlerin ileri derecede zorbalık ve insanlık dişı doğasını tarihi süreç içinde ele almıştır. İnfaz anının izleyen kitleler üzerinde yaptığı etkinin seyirlik potansiyeline vurgu yapan Larson, bu tarz görselliğin ön planda olduğu infazların vahşice bir güç gösterisi olduğunu ifade etmektedir. Larson'ın ifadesiyle baş görme, koklama, duyma, tat alma, konuşma, nefes alma, gülme, ağlama gibi işılevleri taşımaktadır. Bedenimizin ifade gücü en yüksek parçası olan yüz baştadır. Baş dış dünya ve benliğimiz arasındaki en güçlü bağlantıdır. Böylelikle başın bedenden ayrılışı bir insanın ölümünü kitleler nezdinde kesin olarak teyit etme gücüne sahiptir. ${ }^{44}$ Benzer biçimde Ronald Jones da kafa keserek infazın sembolik önemine işaret etmektedir. Jones'a göre baş bilgelik ve bilinci taşır ve dolayısıyla ruhun öte dünyaya transferini sağlar. ${ }^{45}$ Böylelikle başın gövdeden ayrılması cesedi insansı özelliklerinden de ayırmakta ve nesneleştirmektedir.

3.4.3. Yakarak Infaz: Şekil 15 'te DAEŞ'in propaganda filminden Ürdünlü pilot Moaz al-Kasasbeh'in infazına ait görüntüler ${ }^{46}$ yer almaktadır. Videoda infaz öncesi pilot bombalanan alanda dolaştırılıyor, adeta günahlarıyla yüzleştiriliyor. Bu görüntülerin arasında bombardıman sonrası acı çekenlerin dehşet

44"Why Beheading is "The Ultimate Tyranny", https://www.bostonglobe.com/ideas/2014/11/01/whybeheading-ultimate-tyranny/Z7MH52cVtwYSjsmS8G32MJ/story.html, (Erişim: 6.04.2018).

45 Roland H. Jones, “Terrorist Beheadings: Cultural and Strategic Implications”, June 2005, p.2, https://library.uoregon.edu/ec/e-asia/read/behead.pdf, (Erişim: 21.04.2018).

46 "Warnıng, Extremely Graphic Video: ISIS burns hostage alive," Fox News Video, 18:19-18:35, http://video.foxnews.com/v/4030583977001/?\#sp=show-clips, (Erişim: 05.09.2017). 
verici görüntüleri yer almaktadır. Ölümden sonra günahkârların cezalandırma biçimine gönderme yapılarak tanrısal otoriteyi İslam devleti adına kullanmanın vurgulandığı görülüyor. Yakma eyleminin haklılığı pilotun yol açtı̆̆ 1 y1kım görüntüleriyle güçlendiriliyor.
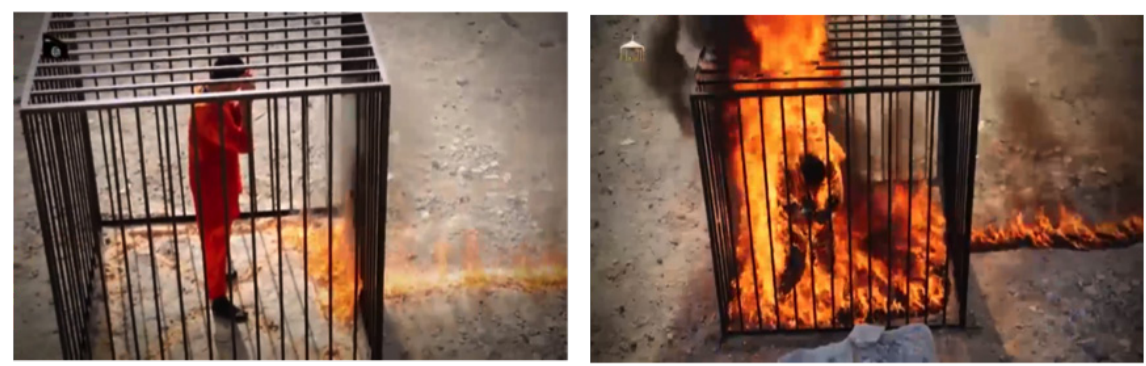

Şekil 15: DAEŞ propaganda filminde Ürdünlü pilot Moaz al-Kasasbeh 'in infaz görüntüleri

İnfaz edilen kişinin kafese konulması da önemli bir unsurdur. Adeta kurbanın imajı avlanmış bir hayvan konumuna indirgenerek katledilmesine meşru bir anlam kazandirilıyor.

\section{Sonuç}

İknânın temel hedefi insan aklı ve nihai amacı ise tutum ve davranış değişikliğidir. Propagandanın terör örgütleri tarafindan kullanımı terörün tarihiyle özdeştir. İletişim teknolojilerindeki gelişmeler propagandanın şeklini ve içeriğini değiştirmiş ve terörün yarattığ 1 korku iklimini tüm dünyaya daha hızlı yaymasına da imkân sağlamıştır. Terör örgütleri bazen ideolojilerini, fikirlerini yaymak, bazen kendilerine taraftar toplayabilmek ve nihayetinde "haklı" olunduğu algısını oluşturabilmek için film, dizi, oyun vb. popüler kültür unsurlarını, sosyal antropolojik kodlar bağlamında kullanmaktadırlar. Böylelikle mevcut kitlenin değer seti incelikli biçimde simüle edilerek yakınlık hasıl edecek bir atmosfer kurgulanmaktadır. Propaganda faaliyetlerinde bahsi geçen kodların içindeki mitsel öğeler, özellikle 'mücahitlik', 'şehitlik' gibi kahraman arketipiyle ilişkilendirilebilecek kavramlar kitlenin kolaylıkla özdeşleşebileceği hikayeler oluşturulmasında kullanılmaktadır.

İncelenen videolarda DAEŞ'in dünyanın hemen hemen her bölgesinde popüler olan savaş oyunlarını, film ve dizileri ustalıkla seçtiği, bu yapımların bilinen sahnelerini kopyalayarak bir benzerini gerçek hayata uyarladığı görülmektedir. Sahnelerin çekim açıları, kullanılan teçhizat, çekim kalitesi vb. unsurların profesyonelce seçildiği ve uygulandığı anlaşılmaktadır. Ayrıca DAEŞ'in pasaport yakma vb. sahnelerde örgüt kimliğini ve aidiyet duygusunu kültürel, dilsel, coğrafi, simgesel verileri kullanarak ustaca işlediği görülmektedir. Hatta şiddetten çok daha öte olan ve barbarca diye tarif edilebilecek eylemlerinde dahi coğrafi özellikleri, farklı milletlerden insanların yaşam alışkanlıklarını, tutumlarını, kültürlerini, dillerini, dinlerini, inanışlarını, eğlence, seyahat ve dinlenme tercihlerini ve hatta oyunların profesyonelce analiz ederek propagandalarında kullanabilmektedirler. 
Propaganda videolarında gerçek olduğu izlenimi yaratılan görüntüler adeta bir "Hollywood yapımı"ndan alınmış anlatı özellikleri ve kurgusal dili taşımaktadır. Bu durum aynı zamanda Baudrillard'ın ${ }^{47}$ çağımızın temel hastalı$\breve{g} 1$ olarak adlandırdığ 1 "gerçeğin üretimi ve yeniden üretimi" ile de ilgilidir. Videolarda gerçekten yaşanan bir savaşa ait görüntüler vardır. Ancak ham malzeme üzerinde gerçeğin destansı bir yeniden üretimini sağlamak üzere teknik müdahaleler yapılmıştır. Örneğin başın gövdeden ayrılması suretiyle infaz birkaç saniyede gerçekleşirken, aynı görüntü farklı açılardan, zaman esnetilerek, estetik etki yaratmak için belli kısımlar çıkarılarak yeniden kurgulanmaktadir. $^{48}$

Şiddetin estetize edildiği anlatı formu özellikle henüz terör örgütüne inisiyasyon sürecini tamamlamamış ve terörün kirli doğasıyla gerçek dünyada yüzleşmemiş kitle üzerinde ikna edici olabilmektedir. Burada sosyal antropolojik açıdan önemli olan unsur, belli bir estetik hazzı sağlayacak kalitede üretilen materyalin, bilinçdışında ilksel-dürtüsel doğaya hitap ederek, etik ve rasyonel değerlendirmeye meydan vermeyecek bir özdeşleşim yaratmasıdır. Özellikle DAEŞ'in genç hedef kitlesi kendisine sunulan karizmatik mücahit imajı sayesinde mevcut aidiyetlerinden siyrılıp sözde 'İslam Devleti' ve 'Hilafet' olgusuna kayıtsız şartsız biat etmeye rahatlıkla yönlendirilebilmektedir. Propagandanın içeriğinde kitlenin zaten oyun ve dizi ve sinema filmlerinde özdeşleşmeye alışkın olduğu motiflerin kullanılması, bilinçdışı alanda değerlerin değiş tokuşu ile ikna sürecini etkili kılmaktadır.

Terör değişen ve gelişen dünyanın nimetlerini kullanarak kendisini mevcut şartlara hızla adapte etme ve böylece varlığını devam ettirme arayışındadır. $\mathrm{Bu}$ arayış terör örgütlerinin ikna temelli stratejilerinde ve nihai amaçlarına ulaşmada bilimsel verileri, analizleri ve teknolojiyi kullanmalarını da gerektirmektedir. Örgütün ismi her ne kadar belli bir coğrafi alanı işaret etse de, propaganda materyallerinde sınırları muğlak bir 'dijital hilafet devleti' imajı yaratılmak istenmektedir. Böylelikle DAEŞ gerçek egemenlik unsurlarını dijital ortamın nimetlerini kullanarak dönüştürmekte, hedef kitlesi tüm dünya olan bir strateji izlemektedir. Tüm dünyanın bildiği oyunlar, filmler, diziler imajlar ve diğer popüler kültür unsurları üzerinden gerçekleştirdiği propaganda faaliyetlerinde küresel ölçekte geçerli, merkezsizleşmiş bir değer düzleminden hedef kitlesini yakalamakta, hem antropolojik kodları hem de küresel dinamiklerin dilini eşzamanlı olarak kullanmaktadır. Bu yüzden DAEŞ gibi terör örgütlerinin amaç ve stratejileri çözümlenirken, hedef aldıkları kitlelerin antropolojik verilerini incelikli biçimde tahlil ederek propaganda faaliyetlerini tasarladıkları dikkate alınmalıdır.

47 Jean Baudrillard, Simülakrlar ve Simülasyon, Oğuz Adanır (Çev), (İzmir: Dokuz Eylül Yayınları, 1998), 37.

48 David Carr, "With Videos of Killings, ISIS Send Medieval Message by Modern Method", https://www.nytimes.com/2014/09/08/business/media/with-videos-of-killings-isis-hones-socialmedia-as-a-weapon.html, Sept. 7, 2014, (Erişim Tarihi: 22.05.2018). 


\section{Kaynakça}

AL-Rawi, Ahmed. "Video Games, Terrorism, and ISIS's Jihad 3.0", Terrorism and Political Violence 30, No. 4 (2018): 740-760, https://www.tandfonline. com/doi/pdf/10.1080/09546553.2016.1207633?needAccess $=$ true, (Erişim Tarihi: 20.07.2018).

Awan, Imran "Cyber-Extremism: ISIS and the Power of Social Media", Society, April 2017, 54, No.2 (2017):138-149, https://www.springerprofessional.de/en/cyber-extremism-isis-and-the-power-of-socialmedia/12144602?fulltextView=true, (Erişim Tarihi: 03.09.2017).

Aziz, Aysel. Sosyal Bilimlerde Araştırma Yöntemleri ve Teknikleri, Ankara: Nobel Yayın Dağıtım, 2010.

Bacchi, Umberto. "Isis propaganda threatens new 9/11 in We Will Burn America video", International Business Times, 13 Nisan 2015, https://www. ibtimes.co.uk/isis-propaganda-threatens-new-9-11-we-will-burn-americavideo-1496096, (Erişim Tarihi: 05.09.2017).

Bal, İhsan. "Terör Nedir, Neden Terörist Olunur?” Terörizm: Terör, Terörizm, ve Küresel Terörle Mücadelede Ulusal ve Bölgesel Deneyimler içinde (Der.) İhsan Bal, (sf. 7-24) Ankara: USAK Yayınları, 2006).

Baudrillard Jean. Simülakrlar ve Simülasyon, Oğuz Adanır (Çev), Dokuz Eylül Yayınları, İzmir, 1998.

Berelson, Bernard. Content Analysis in Communications Research. New York: Hafner Press, 1952.

Carr, David. "With Videos of Killings, ISIS Send Medieval Message by Modern Method", The New York Times, Sept. 7, 2014, https://www.nytimes. com/2014/09/08/business/media/with-videos-of-killings-isis-hones-socialmedia-as-a-weapon.html, (Erişim Tarihi: 22.05.2018).

Christensen, Larry, B. Johnson Burke ve Lisa Anne Turner, Araştırma yöntemleri: Desen ve Analiz (Ankara: Anı Yayınları, 2015).

Darıcı, Sefer. "Dijital Oyunlarda Kullanılan Subliminal Mesajların Gerçeklik Algısı Üzerindeki Etkilerine Yönelik Bir Çalışma: Gerçeklik Eşiği Kavramı”, Electronic Turkish Studies 10.14 (2015).

Demir, Cenker Korhan. "Öğrenen Örgütler ve Terör Örgütleri Bağlamında PKK.”, Uluslararası Illişkiler/International Relations, (2008): 57-88.

Eriksen, Thomas Hylland. "A darker shade of pale: Cultural intimacy in an age of terrorism." Anthropology Today, 27(5) (2011): 1-2. 
Giddens, Anthony. The Consecuences of Modernity, Stanford, CA: Stanford University Press, 1990.

Haviland, William A, Prins Harald E.L., Walrath Dana ve McBride Bunny. Kültürel Antropoloji. Çev. İnan Deniz Erguvan Sarığlu, İstanbul: Kaknüs Yayınları, 2008.

Huizinga, Johan. Homo Ludens A Study of the Play-Element in Culture, London: Routledge \& Kegan Paul, 1980.

Jones, Roland H. "Terrorist Beheadings: Cultural and Strategic Implications", June 2005, p.2. https://library.uoregon.edu/ec/e-asia/read/behead.pdf, (Erişim Tarihi: 21.04.2018).

Juergensmeyer, Mark "Religious Terrorism as Performance Violence", The Oxford Handbook of Religion and Violence içinde (Der.) Mark Juergensmeyer, Margo Kitts ve Michael Jerryson, (sf.280-292), New York: Oxford University Presss, 2013.

Kazan, Hüseyin. "Terör-Medya İlişkisi ve Medyada Terör Haberciliği." Güvenlik Stratejileri Dergisi, Say1: 24 (2016): 109-146.

Kuznar, Lawrence A.. "Rationality wars and the war on terror: Explaining terrorism and social unrest." American Anthropologist, 109(2) (2007): 318-329.

Lucas, Scott. "Syria Interview: Islamic's State of Iraq's Abu Summayah al Britani on Conflict and Caliphate" 11 June 2014, http://eaworldview. com/2014/06/syria-interview-islamic-state-of-iraq-abu-sumayyah-al-britaniconflict-caliphate/, (Erişim Tarihi: 06.09.2017).

Öğülmüş, Selahiddin. "İçerik çözümlemesi." Ankara Üniversitesi Eğitim Bilimleri Fakültesi Dergisi, 24(1) (1991): 213-228.

Macias, José. "The tragedy of terrorism: Perspective, reflection, and action in the aftermath." Anthropology \& Education Quarterly, 33(3) (2002): 280-282.

Mohawk, Jeanette. "Terrorism in Native America: Interrogating the Past, Examining the Present, and Constructing a Libefatory Future." Anthropology \& Education Quarterly, 33(3) (2002): 317-330.

NG, Kelly. "ISIS video shows terror battle is about winning young hearts, minds" Today, 23 Mayis 2016, http://www.todayonline.com/singapore/ISISvideo-shows-terror-battle-about-winning-young-hearts-minds-eng-hen, (Erişim Tarihi: 04.09.2017).

Patton, Michael Quinn. Qualitative Evaluation and Research Methods, Thousand Oaks, CA, US: Sage Publications, Inc., 1990. 
Polat, Gözde Dalan. “İletişim Antropolojisi Üzerine Bir Deneme.” Global Media Journal: Turkish Edition, 6(12) (2016): 513-527.

Smith, Herman. . Strategies of social research: The Methodological Imagination. New Jersey: Prentice Hall. 1975.

Sundar, Nandini. "Toward an Anthropology of Culpability." American Ethnologist, 31(2) (2004): 145-163.

"Warnıng, Extremely Graphic Video: ISIS burns hostage alive," Fox News Video, 18:19-18:35, http://video.foxnews.com/v/4030583977001/?\#sp=showclips, (Erişim Tarihi: 05.09.2017).

Wedel, Janine R., Chris Shore, Gregory Feldman ve diğerleri. "Toward an anthropology of public policy" The ANNALS of the American Academy of Political and Social Science, 600 No.1 (2005): 30-51.

"Why Beheading is 'The Ultimate Tyranny", https:/www.bostonglobe.com/ideas/2014/11/01/why-beheading-ultimate-tyranny/ Z7MH52cVtwYSjsmS8G32MJ/story.html, (Erişim Tarihi: 6.04.2018).

Wood, Graeme. "What ISIS Really Wants", The Atlantic, March 2015, https://www.theatlantic.com/magazine/archive/2015/03/what-DAEŞ-reallywants/384980/, (Erişim Tarihi: 03.09.2017).

Writer, Jeanette Haynes. "Terrorism in Native America: Interrogating the past, examining the present, and constructing a liberatory future.", Anthropology \& Education Quarterly, 33.3 (2002): 317-330.

Yıldırım, Ali ve Hasan Şimşek, Sosyal Bilimlerde Araştırma Yöntemleri, Ankara: Seçkin Yayınevi, 2013.

Youssef, Kinda. "ISIS From the Dark Fiction of Hollywood", Re-Visions, 5 (2015), http://www.re-visiones.net/spip.php\%3Farticle151.html, (Erişim Tarihi: 03.09.2017).

Zulaika, Joseba. "Mythologies of Terror: Fantasy and Self-Fulfilling Prophecy in U.S. Counterterrorism", Kroeber Anthropological Society, 102(1) (2012): 3-19.

\section{Ek 1: Araştırmaya Konu Olan DAEŞ videolarının linkleri}

https://jihadology.net/2017/01/24/new-video-message-from-the-islamicstate-knights-of-the-departments-wilayat-ninawa/

https://jihadology.net/category/the-islamic-state/wilayat-al-barqah/ 
https://jihadology.net/2018/05/22/new-video-message-from-the-islamicstate-conquer-the-enemies-wilayat-kirkuk/

https://jihadology.net/2017/04/19/new-video-message-from-the-islamicstate-the-war-recorded-wilayat-al-fallujah/

https://jihadology.net/2017/03/18/new-video-message-from-the-islamicstate-and-you-will-be-superior-wilayat-ninawa/

https://jihadology.net/2016/09/07/new-video-message-from-the-islamicstate-the-glory-of-jihad-wilayat-al-barakah/

https://jihadology.net/2017/07/30/new-video-message-from-the-islamicstate-conflict-from-the-tribes-wilayat-al-raqqah/

https://jihadology.net/2017/11/10/new-video-message-from-the-islamic-statesnipers-of-the-south-wilayat-al-janub/

EK 2: DAEŞ Videolarıyla Karşılaştırmalı Çözümlenen Oyunların Tanıtım Linkleri

Call of Duty: https://www.youtube.com/watch?v=LhuljNSg7Gg

Sniper Ghost Warrior: https://www.youtube.com/watch?v=0WL9O2ljahs

Grand Theft Auto: https://www.youtube.com/watch?v=XiEQHvfrc98

Medal of Honor: https://www.youtube.com/watch?v=16xsRYdr_SE 